\title{
Wildfires in Grasslands and Shrublands: A Review of Impacts on Vegetation, Soil, Hydrology, and Geomorphology
}

\author{
Ilan Stavi (i) \\ Dead Sea and Arava Science Center, Yotvata 88820, Israel; istavi@adssc.org
}

Received: 2 April 2019; Accepted: 16 May 2019; Published: 20 May 2019

check for updates

\begin{abstract}
Wildfires are prevalent in grasslands and shrublands. The objective of this study is to provide land managers with a general overview, by assessing the main impacts of wildfire, including those on plant communities (e.g., secondary succession and species invasion), soil characteristics (e.g., water repellency (hydrophobicity), aggregation and structure stability, and contents of organic carbon and nutrients), and surface processes (e.g., ash deposition, ground surface clogging, water runoff, soil erosion, hillslope debris flow, and dry ravel). Additionally, the study discusses the effects of livestock grazing on the functioning of post-fire grasslands and shrublands. Although mesic regions are mentioned, this review focuses on drylands. The comparatively low-to-moderate fuel loads that characterize grasslands and shrublands generate wildfires of relatively moderate intensity, resulting in moderate burn severity. Yet, it seems that because of decreased soil aggregate stability following burning, the hoof action of livestock that access burnt lands shortly after the fire increases the shearing and detachment of mineral material from the ground surface; this increases soil erodibility, with the possible risk of accelerated land degradation. The review ends with an assessment of general implications for environmental sustainability and health, and provides recommendations on wildfire control in rangelands, and on restoration of burnt lands.
\end{abstract}

Keywords: climatic change; drought episodes; ecosystem services; herbaceous and woody vegetation community; hillslope processes; invasive species; organic matter; prescribed burning; shrub encroachment; water and wind erosion

\section{Introduction}

Grasslands and shrublands are important for the conservation of floral and faunal biodiversity. Also, they provide a wide range of additional ecosystem services, including carbon sequestration, flood control, soil erosion mitigation, and pasture for livestock [1]. Grasslands and steppes are defined as ecosystems with a tree density of up to 10 trees ha ${ }^{-1}$. Shrublands have been characterized as ecosystems with shrub or sub-shrub densities of at least $30 \%$ cover, plus tree densities of up to 10 trees ha ${ }^{-1}$ [2]. Therefore, the shrubland definition includes garigue, phrygana, chaparral, brush, maquis, and scrub [3]. These lands are vulnerable to increasing anthropogenic pressures, including infrastructures, rural or urban construction, agriculture, and forestry. These disturbances can degrade ecosystems, specifically, through the fragmentation of spatial connectivity, which is needed for the healthy existence of complex systems [4]. One of the major factors that affect grasslands and shrublands across the world is wildfires [5], Figure 1. Although some studies consider wildfires as a disturbance, this article stresses that fires are an important ecological factor that fill crucial roles and functions in grasslands and rangelands [6]. 


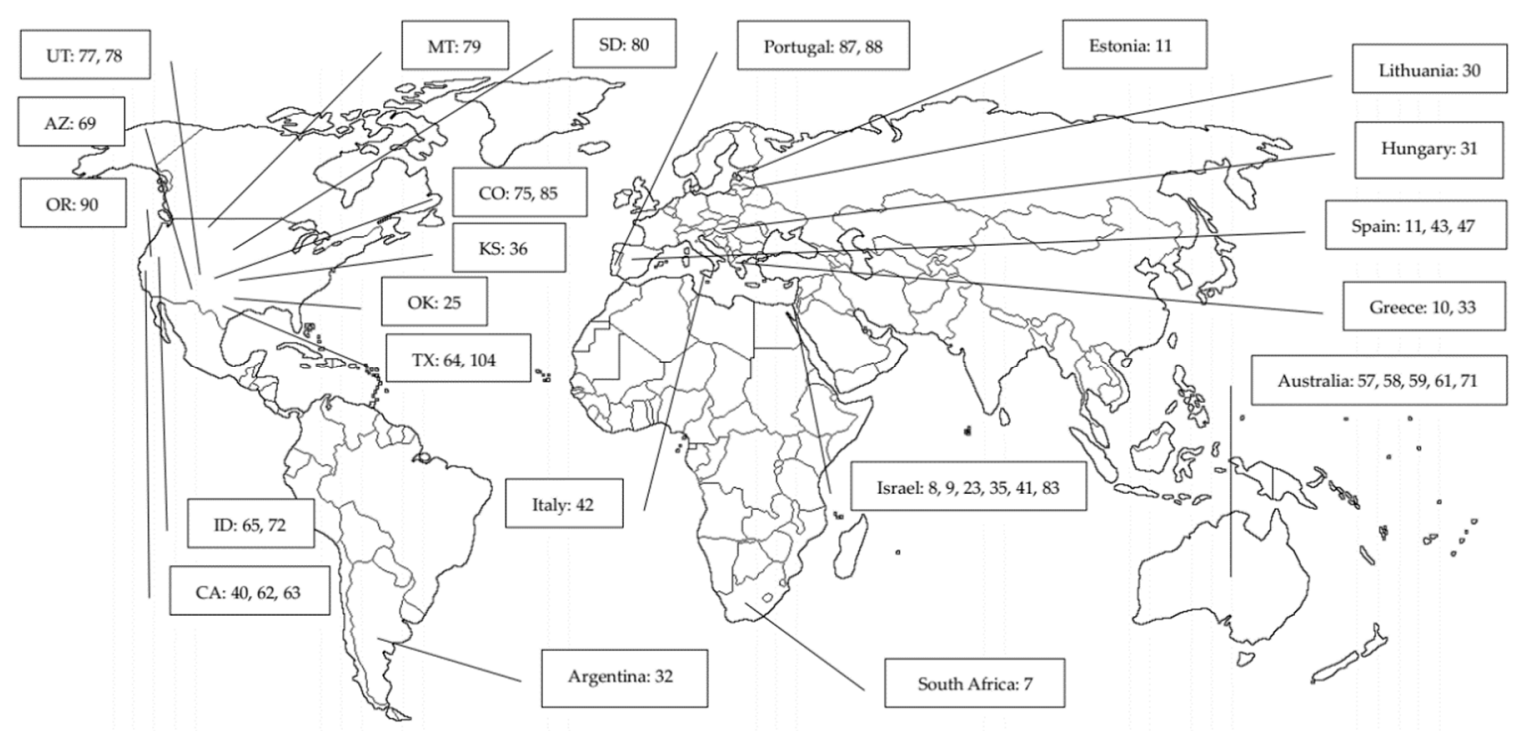

Figure 1. The world map, indicating sites of key studies (for more details, follow the numbers in the list of references).

Among the main factors that determine the behavior of fires, the most important is the fuel load quantity and quality. In this regard, greater quantities of fuel elevate the fire's burning potential, and long dry periods enhance flammability and increase probability of wildfires in these ecosystems. Compared to forests, the availability of fuel in grasslands and shrublands is low; however, this fuel is very dry. Therefore, fire intensity in these lands is relatively low [7], but fires spread fast. Quantities of available fuel in grasslands and shrublands range between $2-10 \mathrm{Mg} \mathrm{ha}^{-1}$, all of which is burnt during a typical wildfire. In comparison, the quantity of available fuel in woodlands and forests ranges between 10-50 $\mathrm{Mg} \mathrm{ha}^{-1}$ and 200-1500 $\mathrm{Mg} \mathrm{ha}^{-1}$, respectively, of which only 5-95\% and 5-25\%, respectively, is burnt during a typical wildfire. Prevailing meteorological conditions during a fire dictate fire behavior, in particular, wind velocity and direction, and relative air humidity. In this regard, four ranges of wind velocity have been defined: (1) weak: $<10 \mathrm{~km} \mathrm{~h}^{-1}$; (2) moderate: 10-20 $\mathrm{km} \mathrm{h}^{-1}$; (3) strong: 20-30 $\mathrm{km} \mathrm{h}^{-1}$; and (4) extreme: $>30 \mathrm{~h}^{-1}$. Four ranges of relative air humidity have also been defined: (a) very low: < 10\%; (b) low: 10-20\%; (c) moderate: 20-30\%; and (d) high: $>30 \%$. The likelihood of wildfires increases as the wind velocity increases and relative air humidity decreases [8].

Among the meteorological conditions, the air temperature has the smallest direct effect on the probability of wildfires [8]. Yet, the heat released during wildfires might form a positive feedback by drying the near-surface vegetation at the fire front, thereby expanding the burnt area and increasing the burn severity [7]. In addition, topography is another important determinant of fire development. Overall, the steeper the hillslope incline, the faster the fire front can advance uphill. Three ranges of hillslope incline have been defined: (i) gentle: < 10\%; (ii) medium: 10-30\%; and (iii) steep: > 30\%. Dry channels can behave as fire corridors (even in the direction opposite to the wind), whereas watershed lines tend to stop the advancement of the fire front. The combination of large quantities of dry fuel and 'suitable' meteorological and topographic conditions constitutes a 'promising recipe' for wildfires [8].

Fires are frequently caused by humans. Although some fires may be ignited accidently, others are a deliberate management practice (prescribed fires), in which the land managers can achieve specific goals, for example, sustaining plant diversity by maintaining a certain frequency of fires [7]. Some fires are started by arsonists. For example, in Israel, about one-third of wildfires between 2012 and 2015 fit this definition [9]. Such ignitions, mostly of forests, have been named pyro-terrorism, and have occurred in other countries as well, including Greece [10] and Spain. The threat of pyro-terrorism has also been reported for Estonia [11] and the United States [12]. 
The following terms are important for discussing wildfires. Fire intensity represents the energy that is released during the different stages of fire. Fire intensity is measured in energy units (e.g., $\mathrm{kW} \mathrm{m}^{-2}$ ) released over a certain time interval along the fire front. Fire severity quantifies the above- and below-ground vegetal material that is consumed by fire. This term is helpful in describing burnt lands, where knowledge gaps exist regarding their fire intensity $[7,13]$. Further, the greatest proportion of heat released in fire is transferred to the air, whereas only a small share of it is transferred to the ground. Therefore, fire intensity is not considered a good indicator for changes in soil properties. The heat which reaches the ground surface is transferred into the soil profile through a combination of different processes, including radiation, conduction, convection, mass transport, vaporization, and condensation [14]. Burn severity relates to loss of organic matter in the soil and represents the degree of soil burning [15]. Ecosystem response includes burning-derived processes, such as soil erosion, vegetation modifications, and faunal changes [13]. Fire regime refers to the type of wildfires, their seasonality, and frequency [7].

Despite the general consensus regarding a global warming trend, e.g., [16,17], forecasting for future precipitation regimes is highly complex. Overall, it seems that future changes in precipitation are latitude- and region-dependent. It is generally agreed that precipitation will decrease throughout the low latitudes and sub-tropics [18], as well as in the world's Mediterranean climatic regions [19]. The low-to-mid latitudinal drylands are forecasted to expand and become drier because of increased evaporation. This aridity is expected to cause mass mortality of vegetation, resulting in accelerated land degradation [18]. Specifically, dried vegetation coupled with low relative air humidity will increase the frequency and intensity of wildfires [5,8]. In turn, the wildfires release large quantities of greenhouse gases (GHGs) to the atmosphere, generating a positive feedback which accelerates global warming [20].

The objective of this study is to provide land managers with a general overview, by discussing and synthesizing the major impacts of wildfires in grasslands and shrublands, focusing on the main effects on vegetation, soil, and surface processes. Additionally, this study reviews the impact of livestock on the functioning of burnt lands, as well as the means for controlling wildfires and restoring of burnt lands. Although mesic regions are not omitted from this review, the focus is predominantly drylands.

\section{Impacts of Wildfires on Vegetation}

In the immediate and short term, wildfires remove or reduce aboveground vegetal biomass [21]. However, in the medium and long term, the effects of wildfires are more complex. For example, plants that are exposed to fire at different phenological stages are affected differently [22]. Among the phenological stages, the most relevant are the post-flowering to seed-ripening, seed dispersal, and germination. Regardless, the productivity of some perennial herbaceous plants is positively affected by fire, for example, due to the decreased competition for water and light. Also, greater net primary productivity is expected following the increased availability of nutrients in the burnt ecosystem. Particularly, plant-assimilated nitrogen becomes accessible for uptake by the regenerating vegetation after being released by the burning of biomass [7]. In a study conducted in the dry, sub-humid north of Israel, it was found that the impact of wildfires on vegetation cover ranged between neutral to a positive effect [23]. In Texas, USA, the impact of wildfires on species composition was reported to be moderate and short-term [24], whereas a considerable and longer-term effect included a decrease in species richness and the replacement of legume and grass species with other herbaceous species [23]. Yet, for the southwestern United States, prescribed patch burnings are widely accepted as a means for increasing plant species diversity [25]. Another possible impact, which is mostly relevant for legumes and other species with seeds covered by a hard coat, is the cracking of this coat by the fire, which accelerates their germination $[7,26]$. An additional important factor is the seasonality of burning. Spring burnings were reported to have a favorable effect on warm-season grasses over cool-season grasses [27], whereas fall burnings favor forbs over grasses [28]. Yet, contradictory effects were also reported [29]. 
Compared to other plant forms, perennial herbaceous vegetation is characterized as being highly tolerant to fire. In typical grassland wildfires, the underground rhizome buds of perennial herbaceous plants remain unharmed [7]. Therefore, restoration of grasslands is relatively fast. For example, following a grassland wildfire in Lithuania, it was reported that the perennial grass, Anthoxanthum odoratum L. (that dominates extensive lands across Eurasia), and the perennial herbaceous plant, Leontodon autumnalis L. (Moench) (a synonym of Scorzoneroides autumnalis L. (Moench), also widespread in Eurasia), recovered fully between 17 and 31 days after the fire [30]. Further, the dependence of some perennial herbaceous species on fire has been demonstrated. For instance, the growth of $\mathrm{C} 4$ species, such as the Themeda triandra Forssk, that is prevalent in Africa, Asia, and Australia, as well as the Andropogon gerardi Vitman that is widespread in Northern America, is suppressed in the absence of wildfires. If wildfires are absent for a decade or more, some of these species may disappear because of the thick layer of plant litter that shades the ground surface and suppresses rhizome buds [7]. Generally, it seems that the impact of wildfire on plant species diversity is context-dependent and may be either negative or positive [31].

One way or another, the fire-induced removal of litter and standing old or dead plant material, resulting in accelerated regrowth of vegetation, increasing the quantity and quality of forage [25]. This effect is particularly relevant for rangelands experiencing long-term overgrazing, leading to encroachment of unpalatable shrub and herbaceous vegetation species. This accords with Guevara et al. [32], who reported a considerable change in plant community composition in the Argentinian Mendoza plains, where fire converted a dense shrubland to a more favorably-balanced grazing land. In this case, the cover of palatable grasses and herbaceous forage biomass increased by a factor of three at the expense of woody vegetation. However, such an effect may be limited for shrub species with a vigorous regeneration capacity. For example, Papanastasis [33] reported for the phryganic rangelands of northern Greece-which are dominated by the dwarf shrub species Sarcopoterium spinosum L. Spach (that is also prevalent in extensive lands across the Mediterranean Basin) - a considerable reduction in cover following burning, but almost full regeneration within three years. Yet, the regeneration capacity of this species is considerably and negatively affected by the burning frequency. The season in which burning occurred, however, does not affect regrowth of this species [33].

In certain circumstances, wildfires might cause the secondary succession of climax vegetation. Specifically, such a process defines events in which an increase in intensity and frequency of fire encourages the dominance of pyrophytes, which are fire resistant species [34]. Perevolotsky et al. [35] distinguished between passive and active pyrophytes: the former includes species that are fire-resistant due to mechanisms such as hard coated-seeds or underground storage organs (geophytes), whereas the latter type includes species whose growth is accelerated by fire, for example, by increasing the rate of seed dispersal.

An increase in intensity or frequency of wildfires may elevate infestation by invasive plant species [34]. For instance, the fire-resistant Lantana camara L. (an invasive shrub species native to the American tropics) were reported to infest wildfire-prone lands in South Africa [7]. Generally, it has been suggested that wildfires encourage the spread of invasive species that have seeds with a hard coat, such as legumes. In Hungarian grasslands it was found that wildfires increased the germination rate of Robinia pseudoacacia L. (an invasive medium-sized hardwood deciduous tree, endemic to a few small areas of the United States), and the invasiveness of the Solidago genus (that includes tens of perennial herbaceous vegetation species of the Asteraceae family, of which most are native to North America) [31].

Regardless, fires have been reported to represent a major pathway of vegetal nitrogen loss in (ungrazed) grasslands and shrublands, resulting in a net reduction in nitrogen mineralization and availability. In turn, this affects the vegetation's shoot-to-root ratio. For example, annual burning in a prairie ecosystem in Kansas, USA, has resulted in a $25 \%$ increase in root growth. This effect was attributed to a mechanism whereby plants compensate for nitrogen limitation imposed by the 
fire, through increasing allocation of biomass to roots. In this ecosystem, roots' C:N ratio under low-frequency burning was reported to be as low as 40 , while under high-frequency burning it increased to 60. In spite of this, frequent burning in prairies was reported to increase the soil respiration, an effect that was attributed to the increased root biomass [36].

\section{Impacts of Wildfires on Soil}

Wildfires also affect soil properties. Increased water repellency (hydrophobicity) is among the most prominent impacts. This soil alteration is an outcome of the fire's high temperature, which causes the vaporization of organic compounds that condense and wrap the soil particles, decreasing the adhesion between them and the water molecules $[14,37,38]$. Soil hydrophobicity is positively affected by the burn severity, as well as by the quantity and flammability of the soil organic matter [14]. The development of hydrophobicity is also related to the soil texture (primary particle size distribution). Overall, coarse-textured soils-where macro-aggregation processes are limited, and therefore, a large share of the organic matter is not enveloped within macro-aggregates-are the most prone to becoming water repellant. Because of water's ability to transfer heat, hydrophobicity is positively affected by the soil-water content [39]. Grasslands and chaparral soils in California, USA, however, exhibited an opposite effect, where water repellency was negatively affected by the soil moisture content [40].

In addition to the soil's absolute temperature, another important determinant of the fire's effect is the temperature gradient throughout the soil profile; the greater this gradient, the more efficient the heat transfer to deeper layers, and the thicker the water repellant layer becomes. Also, hydrophobicity tends to increase with depth because the organic compounds' vapors penetrate to deeper depths (where the temperature is lower) where they condense. Depending on the burn severity, the water repellant layer may develop at a depth ranging from a few millimeters to several centimeters below the ground surface [38,39]. Regardless, fire-induced soil-water repellency decreases over time [40]. Overall, it is apparent that in grasslands and shrublands-which are defined by relatively low-to-moderate burn severity [41] - the impact of wildfires on soil hydrophobicity is short term and does not constitute a considerable disturbance to these ecosystems [30].

An additional considerable impact of wildfires is on the content of organic carbon in soil, which often tends to decrease. However, other outcomes have also been observed. For example, in moderately burnt Sicilian grasslands, the soil organic carbon content was similar before and after the fire [42]. Further, a moderate burning in the Israeli semi-arid Negev was reported to increase the soil organic carbon content [41]. One way or another, a negative impact of fire on the soil organic carbon content causes a decrease in the soil's aggregate stability [43], pore size, and total porosity. These changes in the soil structure might result in a decrease in water infiltration capacity and hydraulic conductivity [14]. Yet, as stated above, a relatively low-to-moderate burn severity that characterizes wildfires in grasslands and shrublands [30,41,42], is not expected to result in this chain of consequences.

Fires also impact the soil microbial biomass and activity [44]. A synthesis study of wildfire impact in different ecosystems assessed an average decrease of 30\% in microbial abundance and of $47 \%$ in fungal abundance. Yet, this study reported that the microbial reactions to fire were site-dependent, and that decreases were observed for forests but not for grasslands [45]. Similar to other soil properties, this effect is attributed to the comparatively low severity of fires in grasslands [46].

The burning of soil organic carbon results in a decrease in cation exchange capacity, and therefore harms the physico-chemical quality of soil. Also, the soil nitrogen content might decrease following its volatilization. Yet, nitrification conditions improve post-fire, increasing the ecosystem's nitrogen availability [25] and pools [21], explaining the increase in the soil total nitrogen content following a moderate-severity burn [41]. In north-east Spain it was reported that low-intensity prescribed burning caused an increase in the soil contents of nitrogen and phosphorus [47]. At the same time, a high frequency of fires might lead to the scarcity of nutrients in the ecosystem $[7,47]$. Fires also modify the soil $\mathrm{pH}$, as seen by an increase in alkalinity [47]. This effect is caused by the destruction of soil organic 
acids [21]. Ash accumulation on the ground contributes to the increase in soil alkalinity. Yet, this effect is much stronger for tropical forests than that of desert grasslands or shrublands.

Ash and charcoal that are formed by fire mix in the ground surface and change the soil color. Generally, due to incomplete burning, low-to-moderate burn severity creates black ash and charcoal, which darkens the soil [48], whereas high burn severity that produces white ash-an outcome of complete burning-brightens the soil [21]. These color changes impact the soil's albedo and temperature [49]. In the event of black ash and charcoal, the increase in soil temperature might be advantageous for the germination of herbaceous vegetation in the early growing season, particularly in mid-to-high latitudinal grasslands and shrublands [50]. At the same time, the elevated soil temperature might increase the loss of water through evaporation [21], decreasing the availability of water for plant uptake. This may negatively impact net primary productivity (NPP), particularly in dry seasons [51] and in low- and mid- latitudes. In certain circumstances, fires might cause a reddish color in soils because of the transformation of iron oxides to hematite or maghemite [52].

\section{Impacts of Wildfires on Surface Processes}

During rainstorms, the decrease in aboveground biomass following fires allows for a higher raindrop splash impact, which detaches mineral material and makes it available for transportation, and simultaneously forms sealed mechanical crusts on the ground surface that increase water runoff [53]. Further, the reduced aboveground biomass accelerates water runoff, leading to increased water erosivity and detachment of soil particles by either rill or interrill erosion [54]. In addition to these processes, which also occur in non-burnt lands, the fire-induced hydrophobicity of soil is expected to further decrease water infiltrability and accelerate water overland flow and soil erosion [55]. Nevertheless, it seems that the hydrophobicity impact is lower than that of the decrease in aboveground biomass [56]. For instance, in a four-year study in Californian grasslands and chaparral, the effects of hydrophobicity on runoff and erosion were separately studied from those of aboveground biomass. It was reported that when combined with a steep hillslope incline, soil erosion was mainly determined by the reduction in aboveground biomass by wildfire. In hillslopes with complete absence of vegetation cover, the runoff rate and soil erosion were considerably greater than those in hillslopes with vegetation patches that survived the fire. At the same time, this study revealed that the importance of soil hydrophobicity for the generation of runoff and erosion was minor. This study also revealed that the transport of the largest share of sediments occurred during the first winter after the wildfire, and that this process took place despite the relatively low precipitations during that winter [40].

Another transport process which characterizes burnt lands is debris flow. In a study in the eastern highlands of Victoria, south-eastern Australia, it was found that the debris quantities in burnt forestlands were two to three orders of magnitude greater than those in non-burnt forestlands. Further, it was reported that burn severity is the strongest predictor for the degree of debris flow. This study also revealed that the hillslopes contributed $18-62 \%$ of the total debris [57]. Indeed, several studies stressed the importance of hillslope debris flow, and noted that this process might take place in hillslopes with different lithologies, as well as in hillslopes covered by different vegetation communities $[57,58]$. In another Australian study, it was found that this process forms paths on the hillslopes, and that its occurrence depends on the combination of certain conditions, including hillslopes of relatively sharp incline, moderate-to-high burn severity, and a considerable mass of gravel (2-64 mm stone size) and cobble (64-256 $\mathrm{mm}$ stone size). The paths are visually identified by the characterizing appearance of catenary lanes of $0.2-1.0 \mathrm{~m}$ width, with deposited stone levees on both sides of the lane. In cases where the hillslope debris flow is sufficiently intense, the combined shear strength of debris and concentrated runoff may form rills or gullies [58]. Because of the relatively high burn severity required for the occurrence of this hillslope process, it seems to be more common in forests $[57,59]$ than in shrublands and grasslands. Yet, post-fire debris flow was also reported to be positively related with aridity [60]. Regardless, debris flow was found to be temporally-dependent, with the greatest occurrence during 
the first winter following the fire, and an exponential decrease in probability from the second winter onward [61].

In addition to the 'wet' erosional processes, burnt lands are also characterized by another type of hillslope process-the gravitational transport of dry ravel-in which material from the hillslopes is transported to the foothills under dry conditions, i.e., without the involvement of water (meaning, transport is not related to either water overland flow or mass wasting/mass movement). This transportation process includes the downslope movement of particles by rolling, bouncing, and sliding, and mostly characterizes arid and semi-arid regions [62]. In chaparral ecosystems in southern California, it was found that wildfires increased the magnitude and extent of dry ravel, making it the predominant process in the transition zone between hillslopes and channels [63]. In another study of Californian grasslands and chaparral, it was revealed that dry ravel was the major transport process of material from the hillslopes to the channels during a fire and closely after it, as well as during the following months, and as long as the dry conditions lasted. Throughout this period, this process allowed the transport of materials in hillslopes with inclines which were gentler than the angle of repose that characterizes the mineral material across the region. Among the visual indications of dry ravel, the most prominent is the local deposition of mineral materials, in cone shapes, at the foothills [40]. It seems that these cones form where lanes on the hillslope's surface allow the concentrated downslope transport of mineral materials, which are then deposited at the foothills [63].

Along with the alluvial and fluvial processes, the decrease in vegetation cover, coupled with the increase in near-surface wind velocity, strengthen the wind's shear stress and raise the risk of wind erosion [64-66]. For example, in the sagebrush (Artemisia tridentata Nutt.) steppe of the Great Basin, western USA, it was found that wildfires increased wind erosion. In addition to soil, this process also depletes nutrients and organic materials from the ecosystem [66]. In a study of grasslands in Texas, it was reported that wind's threshold velocity for detachment of materials from the ground surface increased from $10 \mathrm{~m} \mathrm{sec}^{-1}$ immediately after the fire, to $19 \mathrm{~m} \mathrm{sec}^{-1}$ three months later, during which the vegetation cover has recovered [64]. Further, in addition to the reduction in wind velocity, the vegetation shoots act as dust traps, increasing the deposition of minerals and nutrients in the ecosystem [65-68].

The relatively fast recovery of grasslands and shrublands vegetation, and particularly of perennial grasses [66], makes the magnitude of erosional processes rather moderate in these ecosystems [30]. For instance, in a study conducted in Arizona, USA, it was found that following wildfires, the magnitude of water overland flow and soil erosion was much higher in woodlands than that in grasslands [69]. Also, the moderation of erosional processes in grasslands and shrublands is related to the relatively low-to-moderate burn severity of wildfires that characterize them, with the resultant low hydrophobicity and small (if any) decrease in the soil's organic carbon content and aggregate stability. Therefore, erodibility of burnt grasslands and shrublands is comparatively lower [70] than that of burnt woodlands or forests $[43,71]$. Yet, ash deposited on the ground surface causes it to clog and is prone to erosion by water [14] or wind, and therefore, might deplete resources from the ecosystem [41]. Nevertheless, the relatively low biomass characterizing such ecosystems does not allow fires to exceed low-to-moderate burn severity, and therefore, large quantities of ash are not produced [41,42,48]. A conceptual illustration of wildfire impacts on main surface processes is provided in Figure 2. 


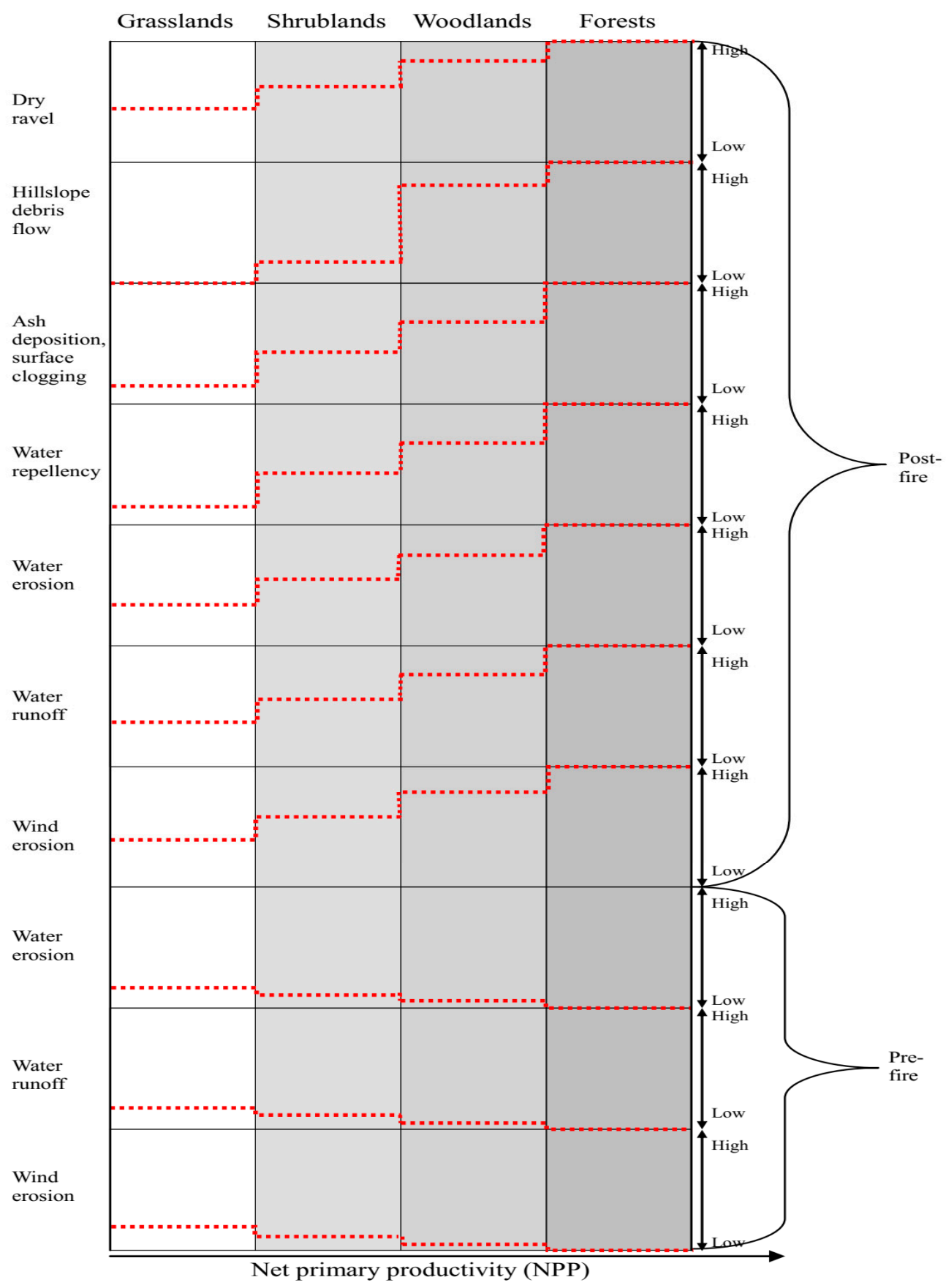

Figure 2. Conceptual illustration of the relative magnitude of the main surface processes under pre-fire and post-fire conditions. Notes: Under pre-fire conditions, well-functioning ecosystems allow the maximal on-site retention of resources. Therefore, wind erosion, water runoff, and water erosion, are low. Yet, the extent of these processes is negatively affected by NPP, and follows the trend of grasslands > shrublands $>$ woodlands $>$ forests. Under post-fire conditions, the reduction in aboveground biomass increases these processes. Yet, the fastest and slowest vegetation recovery in grasslands and forest vegetation, respectively (with the rate of shrublands and woodlands vegetation recovery being in between), dictate the extent of these processes. In addition, fires 'bake' the ground surface, making it water-repellent. Also, ash deposition causes the clogging of the ground surface. These two processes are positively affected by NPP, and therefore, are lowest in the grasslands, and highest in the forests. Hillslope debris flows do not occur in burnt grasslands, and at the same time, are maximal in burnt forests. The extent of dry ravel is similar to that of post-fire processes of wind erosion, water runoff, and water erosion, and is negatively affected by the rate of vegetation recovery. 


\section{Post-fire Ungulate Grazing}

The burning of rangelands affects the activity and movement of both domesticated and wild ungulates. For example, in a semi-arid sagebrush steppe in Idaho, USA, it was found that cattle behavior changed considerably after prescribed fires, and that this behavior persisted even five years post-fire. These changes included increased foraging efficiency by the altered characteristics of cattle activity and movement. Specifically, the foraging paths in burnt rangelands, despite possibly being longer, become less tortuous, allowing the animals to spend more time foraging and less time traveling between vegetation patches [72]. This was explained by the decrease in competition imposed on herbaceous vegetation by woody plants, with the resultant increase in forage production shortly after the fire [73]. This accords with Pearson et al. [74], who reported for the semi-arid grasslands and sagebrush steppe of the Yellowstone National Park, in western USA, that elk (Cervus elaphus) and bison (Bison bison) tended to prefer grazing in post-burnt rangelands, because of greater forage availability than that in non-burnt lands. This is also in accordance with Hobbs and Spowart [75] who reported for the Front Range of Colorado, USA, that prescribed burning increased the protein concentration in winter diets of bighorn sheep (Ovis Canadensis) and mule deer (Odocoileus hemionus) feeding in grassland and mountain shrub communities. This effect was attributed to changes in diet selection by these ungulates, with preference towards grazing in the better-quality forage of burnt lands. Also, post-fire foraging efficiency is greater due to the higher nutrient content of herbaceous vegetation in the season subsequent to fire [76].

In turn, herbivory is expected to impact the vegetation community of the burnt rangelands. For example, it was reported that in semi-arid burnt rangelands in Utah, USA, heavy livestock grazing decreased the density of perennial grasses and increased weed cover [77]. In another study in a sagebrush steppe in Utah, it was shown that livestock grazing 12 to 18 years after a wildfire decreased the total vegetation cover and perennial grass cover, but increased the cover of cheatgrass (Bromus tectorum L., a highly invasive winter annual grass species) [78]. However, for the sagebrush of the Yellowstone's Northern Range, it was reported that post-fire grazing by elk had no detrimental effect on graminoid forage re-growth [76]. Further, in a semi-arid northern mixed prairie in Montana, USA, it was found that up to $50 \%$ biomass removal by cattle grazing in the first growing season after wildfire did not reduce the rangeland productivity, nor shifted species composition in the subsequent year [79]. Similarly, in a northern mixed-grass prairie in South Dakota, USA, it was found that moderate cattle grazing in the first and second growing seasons after a wildfire did not decrease forage productivity. Yet, in terms of plant community composition, post-fire grazing slightly decreased the abundance of $\mathrm{C} 3$ grasses, while increasing the abundance of $\mathrm{C} 4$ grasses, with the resultant lower nutritional quality of pasture [80]. Overall, it seems that post-fire impacts of livestock or wild ungulates on vegetation are case-specific, and particularly dependent on the plant community, as well as on the grazing pressure and seasonality [81].

While the impact of post-fire grazing on vegetation has been extensively researched, studies on the effects of livestock or wild ungulates on soil properties of burnt rangelands are considerably less common [81]. A unique example is a study by Stritar et al. [82], who reported that in the western United States, elk introduced to burnt lands considerably decreased the pools of soil organic carbon, total nitrogen, and microbial nitrogen, as well as the activity of the carbon-acquiring extracellular enzyme (ß-glucosidase). It was concluded that the reduced plant biomass by the browsing herbivores slowed down the ecosystem recovery after wildfires. Another example is a study in the semi-arid Israeli Negev, where the effects of livestock on some physical properties of soil were assessed in a site that has experienced low-to-moderate burn severity. The study was conducted one month after the fire outbreak, in a fallowed cropland that was covered by spontaneous herbaceous vegetation at the time of fire. The study design included plots of four stocking rates, including high, medium, low, and zero (control) stocking rates. Plots of the same design were also established in nearby non-burnt lands. It was found that the fire decreased the soil's shear resistance by $70 \%$. At the same time, the mass of detached material was similar in the burnt and non-burnt lands. Nevertheless, the detached material 
mass in the burnt plots that experienced low, medium, and high stocking rates was threefold, eightfold, and ninefold greater, respectively, than those in the corresponding non-burnt plots that experienced the same stocking rates. Yet, the detachment of the uppermost soil layer by the hoof action negated the moderate hydrophobicity formed by the fire. It was concluded that due to a decrease in the soil's shear resistance following the fire, the livestock hoof action in burnt lands detaches large quantities of mineral material from the ground surface [83]. These effects are illustratively summarized in Figure 3.

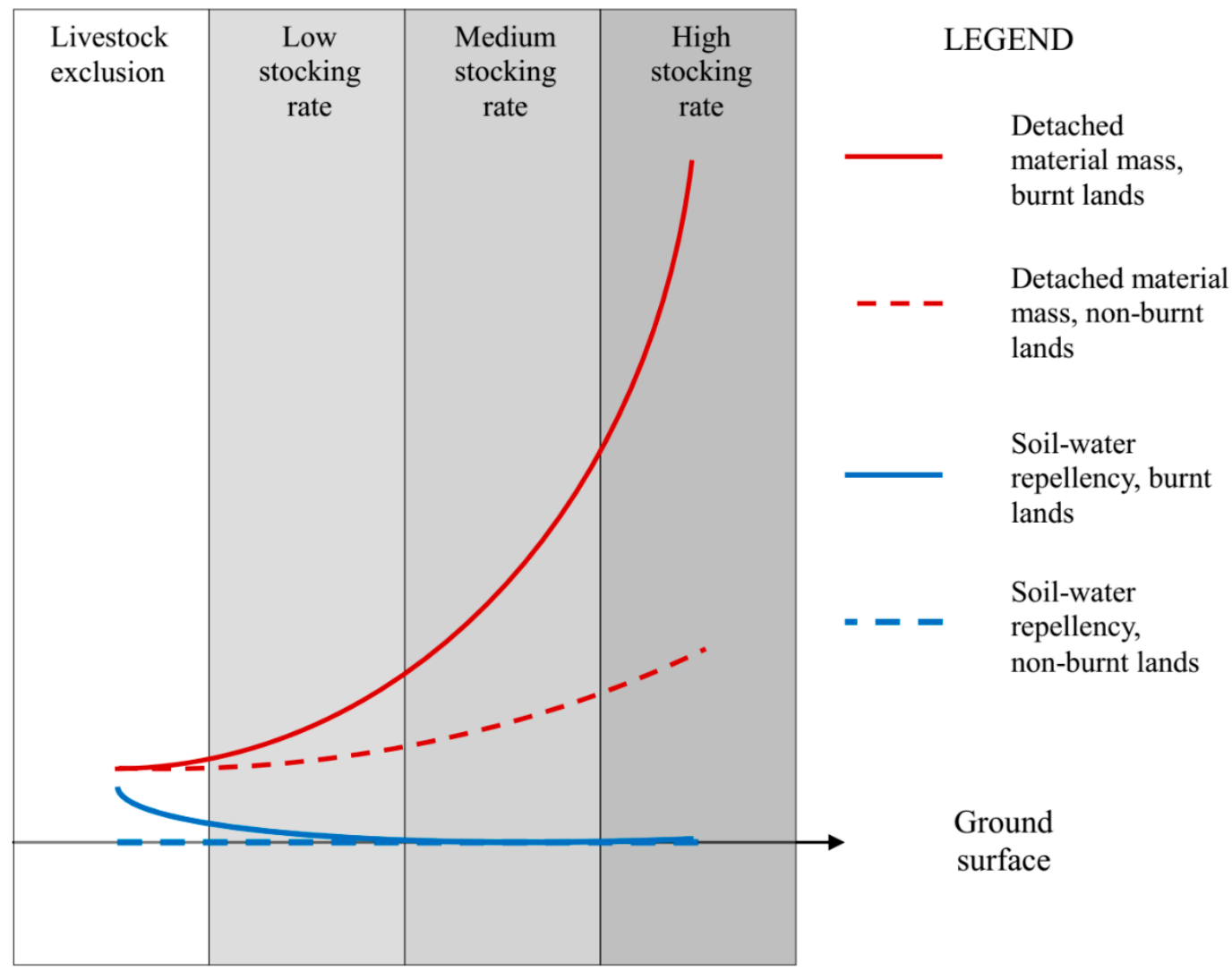

Figure 3. Conceptual illustration of the impacts of stocking rate on detached material mass and soil-water repellency, under burnt and non-burnt lands. Notes: Livestock hoof action shears the uppermost soil layer, with the resultant detachment of mineral material. Elevated stocking rates increases this process. In fire-prone lands, the reduced aggregate stability of soil enables the acceleration of soil shearing and detachment. At the same time, the fire-derived water repellency of the uppermost soil layer is negated by the animal hoof action, which shears the 'baked' ground surface. Modified from Stavi et al. [83].

According to Stavi et al. [83], because of the high erodibility of the detached material by either water or wind, and in order to prevent land degradation, it is recommended to prevent livestock access to burnt lands shortly after the fire event. So far, however, among the topics reviewed and discussed in this study, the post-fire impact of livestock presence on soil properties, and particularly the soil quality and erodibility, is the least studied. At this stage, additional studies on that topic are unknown. Also, changes in the impact of livestock over time after the fire, are unknown.

\section{Environmental Implications, and Recommendations for Land Managers}

In addition to the onsite effects of wildfires discussed in the previous sections, wildfires pose considerable off-site impacts. Among these, modifications in the watershed hydrological regime is most prominent. Specifically, a generally adverse impact on the quality of surface- and ground-water sources has been extensively reported [84]. For example, many studies highlighted the potential 
of forest wildfires to pollute rivers, lakes, and underground aquifers with sediments, nutrients, and trace elements $[85,86]$. Also, forest fires were reported to considerably increase concentrations of heavy metals in water sources [87]. Additional potential contaminants are the polycyclic aromatic hydrocarbons (PAHs), which are organic pollutants produced during combustion, and are known to be highly toxic for aquatic organisms, as well as for humans [88]. Yet, compared with forest fires, it is expected that the relatively lower magnitude of geomorphic processes in shrubland and grassland wildfires impose lesser risk of water source contamination.

Climatic changes, which include the drying of extensive lands around the world, might cause an increase in intensity and frequency of wildfires $[18,89,90]$. For instance, an analysis of historical records of rangeland wildfires in the western United States showed that dry conditions combined with high temperatures have led to an increase in the intensity and frequency of fires [91]. However, some models predict that a decrease in precipitation will reduce the NPP of grasslands and shrublands, and therefore, reduce the intensity and frequency of wildfires. At the same time, other models project that an increase in precipitation will cause a rise in the NPP of these ecosystems, resulting in greater intensity and frequency of fires [92]. Analyses of the above-mentioned historical records suggest that the highest risk of wildfires occurs when a rainy year, during which large quantities of fuel have accumulated, is followed by a drought year [91]. Certain models foresee that during the 21st century, the extent of wildfires will decrease in the lower latitudes, i.e., in the tropics and sub-tropics [92]. At the same time, analyses based on these models and the above-mentioned historical records predict that the intensity and severity of wildfires will increase in the middle latitudes, i.e., in the temperate regions [91,92]. Also, it was proposed that the interactions between wildfire regimes and secondary succession in plant communities of forests, shrublands, and grasslands is more affected by short-term droughts than by long-term climatic changes [91].

Grasslands and shrublands are considerable carbon sinks; therefore, they regulate the global carbon cycle [93]. Carbon dioxide $\left(\mathrm{CO}_{2}\right)$, which constitutes the main component of the gas emitted to the atmosphere in wildfires, is a well-known GHG, causing radiative forcing and global warming $[20,94]$. In the 1990s, the carbon emissions caused by savanna and forest wildfires around the world reached 1.7-4.1 Pg a year [7]. In addition to $\mathrm{CO}_{2}$, wildfires also emit considerable amounts of methane $\left(\mathrm{CH}_{4}\right)$ [94]. The global warming potential of the latter is 21 to 28 times greater than that of $\mathrm{CO}_{2}$ (21-28 $\mathrm{CO}_{2}$ equivalent) [95]. Regardless, the rapid recovery of grasslands allows the fast replenishment of their carbon stocks [96], which regulate, to some extent, the atmospheric concentration of $\mathrm{CO}_{2}$.

In addition to GHGs, wildfires release aerosols [20] which reduce the solar radiation that reaches Earth, and therefore may regulate the global warming trend [95]. It was estimated that wildfire-originated aerosols decrease solar radiation by $2 \mathrm{~W} \mathrm{~m}^{-2}$, enabling global cooling by approximately $2{ }^{\circ} \mathrm{C}$ [7]. Therefore, there is an uncertainty regarding the absolute impact of wildfires on the global climate [95]. In addition to the direct impacts on global climate, wildfires also emit large quantities of pollutant gases, some of which are toxic, such as carbon monoxide (CO), ammonia $\left(\mathrm{NH}_{3}\right)$, nitrogen oxides $\left(\mathrm{NO}_{\mathrm{x}}\right)$ including nitric oxide $(\mathrm{NO})$ and nitrogen dioxide $\left(\mathrm{NO}_{2}\right)$, and sulfur dioxide $\left(\mathrm{SO}_{2}\right)$ [94]. Further, the last three gases are among the main causes of acid rains [97]. Yet, compared to other ecosystems, the relatively small fuel loads that characterize grasslands and shrublands cause moderate emissions of GHGs, other (toxic) gases, and aerosols [98].

In terms of land management, an effective means for reducing wildfires is the establishment of gap strips, aimed at breaking the spatial connectivity of vegetal cover, negating the spread of fire from one land unit to another, and facilitating fire-fighting actions [7]. The gap strips must be routinely maintained to prevent their blurring, which results in reduced effectiveness over time [35]. Also, livestock grazing regulates the quantity and distribution of biomass, determining the availability of fuel. Therefore, the probability of wildfires in rangelands prone to moderate-to-high grazing pressures is lower [7]. Thereby, livestock grazing may be utilized as an effective management means for reducing fires [35]. For example, in a mixed grass-shrub rangeland in south-east Oregon, USA, it was found that winter grazing by cattle during the five years before a prescribed fire decreased the available fine 
fuel and increased the moisture content of this material. A prescribed burning, designed to study the effects of livestock grazing on the ecosystem functioning, revealed that compared to non-grazed lands, the flame height, rate of fire spread, and size of the burnt area were all lower in the grazed lands. Also, in the grazing-prone lands, the fire intensity was lower, as expressed by lesser values of the fire's maximal temperature and heat load. Thus, livestock grazing decreased the mortality risk of important herbaceous vegetation species. Further, it was proposed that winter grazing might regulate the aggravating effect of climatic change on wildfire frequency and intensity [90].

However, over the long run, one must prevent high grazing pressures that may cause secondary succession, in which woody vegetation invades and replaces grasses and other herbaceous vegetation [99]. In New Mexico, it was found that long-term livestock grazing led to the replacement of the predominant perennial grass species Bouteloua eriopoda Torr. by invasive shrub species, and particularly Larrea tridentata (DC.) Coville (creosote bush) and Prosopis glandulosa Torr. (honey mesquite, small to medium-sized, thorny shrub or tree in the legume family) [100]. A similar impact was recorded for central Mexico, where seven years of grazing exclusion resulted in a considerable decrease in cover of the dominant $L$. tridentata shrub species, with the corresponding increase in herbaceous vegetation cover [101]. The positive impact of livestock on shrub encroachment is attributed to the increase in spatial redistribution of water and soil resources that originate in the intershrub spaces and accumulate in the shrubby patches, allowing the increase in woody vegetation cover and overall ecosystem biomass [100]. The woody vegetation is characterized by a high carbon:nitrogen ratio, high fiber content, and high leaf-specific weight, all of which are less attractive for livestock. Thus, ecosystems characterized as having low values for livestock production are those that are more susceptible to wildfires [7]. Further, rangelands prone to high livestock pressures become more susceptible to erosional processes by either water or wind, with the resultant accelerated land degradation [102]. Therefore, rangelands should be constantly monitored and judiciously managed, aiming to achieve balanced grazing. A conceptual illustration of the impacts of livestock pressure on vegetation properties, with the resultant effects on wildfire regime and rangeland functioning, is presented in Figure 4.

In many countries, prescribed burning regimes encompass an integral part of rangeland management, and aim at preventing the encroachment of grasslands by woody plants [89,103], or sustaining species diversity of vegetation. Also, in some countries, prescribed burnings may be used to prevent wildfires by reducing large quantities of fuel, which might cause intense fires that would generate severe geo-ecological outcomes [7]. In such events, caution should be exercised to verify that the fire's frequency and intensity do not exceed certain levels, which might prevent the replenishment of the ecosystem resources [47] or accelerate erosional processes. A specific type of prescribed burning is the patch burning practice, where sections of a landscape unit are purposely burnt on a shifting basis, creating a cyclic burning mosaic of habitats across the landscape. This practice decreases the amounts of standing biomass and litter, while promoting plants regrowth, and increasing vegetation species diversity. The fresh vegetation in these land units attracts livestock, causing preferential grazing of them [104]. Studies from Oklahoma, USA, showed that patch burning is beneficial for livestock production, reducing the need to provide the animals with supplementary protein-rich feed [25]. The patch burning system can also assist in controlling invasive plant species [22]. For example, in the south-western United States, this practice was reported to effectively control the invasion of Juniperus virginiana L. (a dense, slow-growing coniferous species, with a shrub or tree morphology) and Lespedeza cuneate (Dum.Cours.) G.Don (a perennial herbaceous species, with branching stems reaching a maximum height of $2 \mathrm{~m}$ ). The size and spatial pattern of burnt patches should match the specific management goals. This practice is extensively utilized in southern and western United States, where it is usually conducted in three-year cycles, and eliminates the need for fencing or other expensive management practices [25]. 


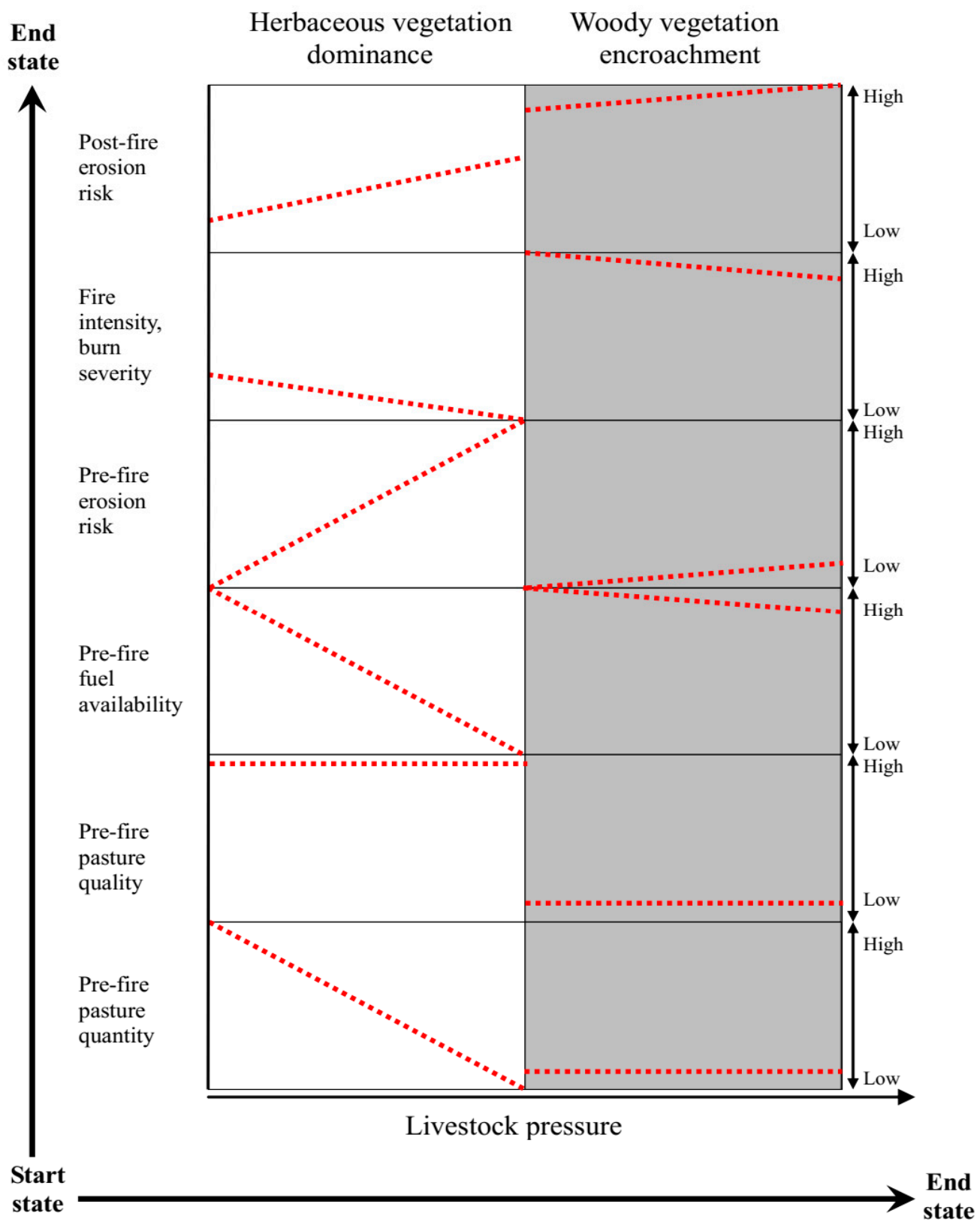

Figure 4. Conceptual illustration of the relative characteristics of grasslands and shrublands. Notes: In grasslands dominated by herbaceous vegetation, aboveground biomass is maximal, but decreases with an increase in livestock pressure. The pasture quality of these lands is high. The increase in livestock pressure reduces the available fuel, and at the same time, increases the risk of erosion. In the event of wildfires, the increase in livestock pressure decreases the fire intensity and burn severity, and at the same time, increases the erosion risk. Under pre-fire conditions, the increase in livestock pressure allows the encroachment of woody vegetation, which is characterized by low quantity and quality of pasture. At the same time, the high quantities of aboveground biomass of these ecosystems provide high quantities of fuel, but this is moderately controlled by livestock pressure. The soil erosion risk of these ecosystems is rather low, but slightly increases with increasing livestock pressure. In the event of wildfires, fire intensity and burn severity are high, and slightly decrease with an increase in livestock pressure. The post-fire erosion risk is high, and increases with a rise in livestock pressure.

In any case, in burnt rangelands, soil erosion and land degradation risks are often high, necessitating passive or active means for allowing ecosystem recovery. The exclusion of livestock after fire is the most prominent passive means of recovery. Yet, there are very limited data evaluating the optimal time 
of livestock exclusion, e.g., [24]. The length of time necessary for the plant communities and entire ecosystems to recover before allowing grazing depends on several interacting variables. Among these variables, the pre-fire state of geo-ecosystem, plant community, fire severity, resilience to disturbance, resistance to invasiveness, climatic conditions, and post-fire grazing regime are the most important. Overall, there is a general consensus on grazing exclusion during the first growing season following fire. However, grazing impacts during the second year after fire are less clear. One way or another, in the United States, federal recommendations for post-fire management of rangelands includes grazing exclusion for two growing seasons after fire to allow for self-recovery processes [81].

Nevertheless, in severely degraded burnt rangelands, the exclusion of livestock might not suffice, necessitating active restoration practices. Implementing such practices should be carried out very cautiously in order to prevent degradation processes. Also, it is preferable to conduct these active practices in small land units, rather than in extensive areas. Generally, the ground surface should not be disturbed. Nevertheless, in certain cases, the use of minimum-till drills for the seeding of native, introduced, or cultured herbaceous vegetation might be considered. Despite increasing the risk of soil erosion in the immediate to short run, this management practice might support the development of annual and perennial vegetation for the mid- to long-term. In such events, species with relatively large seeds (that are less prone to transport by water or wind), and those that rapidly germinate and develop, particularly under harsh conditions, are preferable. At the same time, intensive tillage should be avoided, as well as the use of heavy machinery [66]. One way or another, any restorative intervention should be closely monitored and its benefits and risks should be carefully assessed.

\section{Conclusions}

Wildfires are widespread in grasslands and shrublands of the world. Overall, it seems that the biotic and physical effects of fires are not necessarily detrimental. Instead, wildfire impacts are site-specific and context-dependent. Further, in addition to the prevailing pre-fire physical and biotic conditions, the timing (i.e., seasonality) of fire is an important factor in determining its impacts. Therefore, controversies exist regarding some of the impacts of fire on vegetation community, soil properties, and surface processes, as well as regarding the effects of post-fire grazing on rangeland functioning. Concordantly, selecting best practices for pre- and post-fire management of rangelands are highly varied. This study, however, does not aspire to cover all the possible impacts of wildfires in grasslands and shrublands, nor to discuss all the relevant implications. Instead, this study aims at providing land managers with a general overview, by pointing out the major effects of fires and their main consequences. Overall, this review study reveals three broad conclusions. The first is that the midand long-term impact of wildfires on vegetation community is dominated by secondary succession and species invasion. The magnitude of these impacts is dependent on the prevailing physical and biotic conditions, and on the fire frequency and regime. The second general conclusion is that because of the relatively limited fuel availability in grasslands and shrublands, fire intensity is comparatively low, and therefore, the severity of impacts on soil properties and surface processes is relatively moderate. Yet, depending on their physical properties, such as extremely steep terrains or highly erodible soils, post-fire erosion risk of grasslands and shrublands may be high. The third general conclusion is that the relatively low-to-moderate impact of livestock on functioning of burnt rangelands is relevant if grazing is prevented or limited shortly after the wildfire. Because of the possible adverse effect on the soil structural stability, access of livestock to rangelands shortly after the wildfire might accelerate the shear and detachment of mineral materials from the ground surface. In such events, the detached material becomes vulnerable to erosion, harming the geo-ecosystem functioning, and accelerating land degradation. Yet, it is currently unknown how the impact of livestock changes over time after wildfires. The foreseen increase in frequency of droughts, and the expected higher probability of wildfires in grasslands and shrublands, emphasizes the need for additional research on this topic.

Author Contributions: I.S. designed the study, reviewed literature, and drafted the manuscript. 
Funding: The study was funded by the Israel Nature and Parks Authority (Grant \# P018006016).

Acknowledgments: The author is grateful to three anonymous reviewers, whose comments allowed for the considerable improvement of the manuscript.

Conflicts of Interest: The author declares no conflict of interest. The founding sponsors had no role in the design of the study, in the collection, analyses, or interpretation of data, in the writing of the manuscript, nor in the decision to publish the results.

\section{References}

1. Hao, R.F.; Yu, D.Y. Optimization schemes for grassland ecosystem services under climate change. Ecol. Indic. 2018, 85, 1158-1169. [CrossRef]

2. Berg, N.; Perevolotsky, A. National Plan for Monitoring Biological Diversity in the Open Lands of Israel; Israel's National Nature Assessment Program (HaMaarag): Jerusalem, Israel, 2010. Available online: http://www.hamaarag.org.il/sites/default/files/media/file/report/field_report_report_file/\%D7\%AA \%D7\% 9B\%D7\%A0\%D7\%99\%D7\%AA \%20\%D7\%9C\%D7\%90\%D7\%95\%D7\%9E\%D7\%99\%D7\%AA\%20\%D7\% 9C\%D7\%A0\%D7\%99\%D7\%98\%D7\%95\%D7\%A8\%20\%D7\%94\%D7\%9E\%D7\%92\%D7\%95\%D7\%95\% D7\%9F\%20\%D7\%94\%D7\%91\%D7\%99\%D7\%95\%D7\%9C\%D7\%95\%D7\%92\%D7\%99.pdf (accessed on 18 May 2019). (In Hebrew)

3. Clarck, A.N. Longman Dictionary of Geography_Human and Physical; Butler \& Tanner: Essex, UK, $1985 ;$ p. 724.

4. Jongman, R.H.G.; Kamphorst, J.D. The effects of infrastructure on nature. In COST 341 Habitat Fragmentation due to Transport Infrastructure-State of the Arts Report; Europen Co-operation in the Field of Scientific and Technical Research; European Commission: Brussels, Belgium, 2013. Available online: http://www.iene.info/ wp-content/uploads/COST341_NationalReport_Netherlands_UKdef.pdf (accessed on 18 May 2019).

5. Jolly, W.M.; Cochrane, M.A.; Freeborn, P.H.; Holden, Z.A.; Brown, T.J.; Williamson, G.J.; Bowman, D.M.J.S. Climate-induced variations in global wildfire danger from 1979 to 2013. Nat. Commun. 2013, 6, 7537. [CrossRef] [PubMed]

6. Carroll, J.M.; Hovick, T.J.; Davis, C.A.; Elmore, R.D.; Fuhlendorf, S.D. Reproductive plasticity and landscape heterogeneity benefit a ground-nesting bird in a fire-prone ecosystem. Ecol. Appl. 2017, 27, 2234-2244. [CrossRef]

7. Bond, W. Fires, Ecological Effects of. In Encyclopedia of Biodiversity, Volume 2; Academic Press: Cambridge, MA, USA, 2001; pp. 745-753.

8. KKL. Fire Fighting in Forests, Woodlands, and Open Lands; Keren Kayemet Le'Israel: Jerusalem, Israel, 2013. Available online: http://www.kkl.org.il/files/hebrew_files/michrazim/bid-30-15-reference-document-8.pdf (accessed on 18 May 2019). (In Hebrew)

9. Elran, M. Insights from the Wildfires Wave at the National Security Level. Over View 874; The Institute for National Security Studies-Strategic, Innovative, and Policy-Oriented Research; The Institute for National Security Studies: Tel Aviv, Israel, 2016. Available online: https://www.inss.org.il/he/wp-content/uploads/sites/2/ systemfiles/874\%20M\%20E.pdf (accessed on 18 May 2019). (In Hebrew)

10. Repousis, S. Pyro terrorism in Greece? Greek forest fires August 2007 and the impact on Greek banks stocks. J. Money Laund. Control 2018, 21, 163-170. [CrossRef]

11. Deshpande, N. Pyro-terrorism: Recent cases and the potential for proliferation. Stud. Confl. Terror. 2009, 32, 36-44. [CrossRef]

12. Baird, R.A. Pyro-terrorism-The threat of arson-induced forest fires as a future terrorist weapon of mass destruction. Stud. Confl. Terror. 2006, 29, 415-428. [CrossRef]

13. Keeley, J.E. Fire intensity, fire severity and burn severity: A brief review and suggested usage. Int. J. Wildland Fire 2009, 18, 116-126. [CrossRef]

14. Neary, D.G. Impacts of wildfire severity on hydraulic conductivity in forest, woodland, and grassland soils. In Hydraulic Conductivity_Issues, Determination and Applications; Lakshmanan, E., Ed.; InTechOpen: London, UK, 2011; pp. 123-142.

15. Parsons, A.; Robichaud, P.R.; Lewis, S.A.; Napper, C.; Clark, J.T. Field Guide for Mapping Post-Fire Soil Burn Severity; Gen. Tech. Rep. RMRS-GTR-243; Rocky Mountain Research Station, Forest Service, U.S. Department of Agriculture: Fort Collins, CO, USA, 2010. 
16. Schmidt, G.A.; Arndt, D. NOAA/NASA Annual Global Analysis for 2016; NASA: Silver Spring, MD, USA, 2017. Available online: https://www.giss.nasa.gov/research/news/20170118/NOAA-NASA_Global_Analysis-2016FINAL.pdf (accessed on 18 May 2019).

17. WMO. WMO Statement on the State of the Global Climate in 2016; WMO No. 1189; World Meteorological Organization: Geneva, Switzerland, 2017. Available online: https://reliefweb.int/sites/reliefweb.int/files/ resources/1189_Statement2016_EN.pdf (accessed on 18 May 2019).

18. Schlaepfer, D.R.; Bradford, J.B.; Lauenroth, W.K.; Munson, S.M.; Tietjen, B.; Hall, S.A.; Wilson, S.D.; Duniway, M.C.; Jia, G.; Pyke, D.A.; et al. Climate change reduces extent of temperate drylands and intensifies drought in deep soils. Nat. Commun. 2017, 8, 14196. [CrossRef]

19. Polade, S.D.; Gershunov, A.; Cayan, D.R.; Dettinger, M.D.; Pierce, D.W. Precipitation in a warming world: Assessing projected hydro-climate changes in California and other Mediterranean climate regions. Sci. Rep. 2017, 7, 10783. [CrossRef]

20. Sommers, W.T.; Loehman, R.A.; Hardy, C.C. Wildland fire emissions, carbon, and climate: Science overview and knowledge needs. For. Ecol. Manag. 2014, 317, 1-8. [CrossRef]

21. Zavala, L.M.; de Celis, R.; Jordán, A. How wildfires affect soil properties. A brief review. Cuadernos Investig. Geogr. 2014, 40, 311-331. [CrossRef]

22. Ruckman, E.M.; Schwinning, S.; Lyons, K.G. Effects of phenology at burn time on post-fire recovery in an invasive C4 grass. Restor. Ecol. 2012, 20, 756-763. [CrossRef]

23. Malkinson, D.; Wittenberg, L. Recurring Wildfires-Geomorphic and Ecological Effects; A Report to the Ministry of Science, Technology, and Space; University of Haifa: Haifa, Israel, 2015.

24. Wester, D.B.; Rideout-Hanzak, S.; Britton, C.M.; Whitlaw, H. Plant community response to the East Amarillo Complex wildfires in the Southern High Plains, USA. Community Ecol. 2014, 15, 222-234. [CrossRef]

25. Weir, J.R.; Fuhlendorf, S.D.; Engle, D.M.; Bidwell, T.G.; Cummings, D.C.; Elmore, D.; Limb, R.F.; Allred, B.W.; Scasta, J.D.; Winter, S.L. Patch Burning: Integrating Fire and Grazing to Promote Heterogeneity. Publication No. E-998; Department of Natural Resource Ecology and Management, Oklahoma Cooperative Extension Service, Oklahoma State University: Stillwater, OK, USA, 2013. Available online: http://pods.dasnr.okstate.edu/ docushare/dsweb/Get/Document-4677/E-998.pdf (accessed on 18 May 2019).

26. Rasmussen, G.A.; Wright, H.A. Germination requirements of flameleaf sumac. J. Range Manag. 1988, 41, 48-52. [CrossRef]

27. Wright, H.A. Range burning. J. Range Manag. 1974, 27, 5-11. [CrossRef]

28. Daubenmire, R. Ecology of fire in grasslands. Adv. Ecol. Res. 1968, 5, 209-266.

29. Ansley, R.J.; Castellano, M.J. Effects of summer fires on woody, succulent, and graminoid vegetation in southern mixedprairie ecosystems: A review. In Proceedings of the 23rd Tall Timbers Fire Ecology Conference: Fire in Grassland and Shrubland Ecosystems; Masters, R.E., Galley, K.E.M., Eds.; Tall Timbers Research Station: Tallahassee, FL, USA, 2007; pp. 63-70.

30. Pereira, P.; Cerda, A.; Jordan, A.; Bolutiene, V.; Pranskevicius, M.; Úbeda, X.; Mataix-Solera, J. Spatio-temporal vegetation recuperation after a grassland fire in Lithuania. Procedia Environ. Sci. 2013, 19, 856-864. [CrossRef]

31. Deák, B.; Valkó, O.; Török, P.; Végvári, Z.; Hartel, T.; Schmotzer, A.; Kapocsi, I.; Tóthmérész, B. Grassland fires in Hungary-Experiences of nature conservationists on the effects of fire on biodiversity. Appl. Ecol. Env. Res. 2014, 12, 267-283. [CrossRef]

32. Guevara, J.C.; Stasi, C.R.; Wuilloud, C.F.; Estevez, O.R. Effects of fire on rangeland vegetation in south-western Mendoza plains (Argentina): Composition, frequency, biomass, productivity and carrying capacity. J. Arid Environ. 1999, 41, 27-35. [CrossRef]

33. Papanastasis, V.P. Effects of season and frequency of burning on a phryganic rangeland in Greece. J. Range Manag. 1980, 34, 251-255. [CrossRef]

34. Reeves, M.C.; Manning, M.E.; DiBenedetto, J.P.; Palmquist, K.A.; Lauenroth, W.K.; Bradford, J.B.; Schlaepfer, D.R. Effects of Climate Change on Rangeland Vegetation in the Northern Rockies. In Climate Change and Rocky Mountain Ecosystems; Advances in Global Change Research; Halofsky, J.E., Peterson, D.L., Eds.; Springer: Berlin, Germany, 2016; pp. 97-114.

35. Perevolotsky, A.; Lahman, A.; Polak, G. Mediterranean Woodlands-Wildfire Impacts; The Society for the Protection of Nature in Israel: Tel Aviv, Israel, 1992. Available online: https://www.teva.org.il/GetFile.asp? CategoryID=11708\&ArticleID=23793\&ID=10710 (accessed on 18 May 2019). 
36. Johnson, L.C.; Matchett, J.R. Fire and grazing regulate belowground processes in tallgrass prairie. Ecology 2001, 82, 3377-3389. [CrossRef]

37. Doerr, S.H.; Shakesby, R.A.; Walsh, R.P.D. Soil water repellency: Its causes, characteristics and hydro-geomorphological significance. Earth-Sci. Rev. 2000, 51, 33-65. [CrossRef]

38. Letey, J. Causes and consequences of fire-induced soil water repellency. Hydrol. Process. 2001, 15, $2867-2875$. [CrossRef]

39. DeBano, L.F. Water Repellent Soils: A State-of-the-Art; General Technical Report PSW-46; United States Department of Agriculture: Berkeley, CA, USA, 1981.

40. Hubbert, K.R.; Wohlgemuth, P.M.; Beyers, J.L.; Narog, M.G.; Gerrard, R. Post-fire soil water repellency, hydrologic response, and sediment yield compared between grass-converted and chaparral watersheds. Fire Ecol. 2012, 8, 143-162. [CrossRef]

41. Stavi, I.; Barkai, D.; Knoll, Y.M.; Abu Glion, H.; Katra, I.; Brook, A.; Zaady, E. Fire impact on soil-water repellency and functioning of semi-arid croplands and rangelands: Implications for prescribed burnings and wildfires. Geomorphology 2017, 280, 67-75. [CrossRef]

42. Novara, A.; Gristina, L.; Rühl, J.; Pasta, S.; D'Angelo, G.; La Mantia, T.; Pereira, P. Grassland fire effect on soil organic carbon reservoirs in a semiarid environment. Solid Earth 2013, 4, 381-385. [CrossRef]

43. Varela, M.E.; Benito, E.; Keizer, J.J. Wildfires effects on soil erodibility of woodlands in NW Spain. Land Degrad. Dev. 2010, 21, 75-82. [CrossRef]

44. Fultz, L.M.; Moore-Kucera, J.; Dathe, J.; Davinic, M.; Perry, G.; Wester, D.; Schwilk, D.; Rideout-Hanzak, S. Forest wildfire and grassland prescribed fire effects on soil biogeochemical processes and microbial communities: Two case studies in the semiarid Southwest. Appl. Soil Ecol. 2016, 99, 118-128. [CrossRef]

45. Dooley, S.R.; Treseder, K.K. The effect of fire on microbial biomass: A meta-analysis of field studies. Biogeochemistry 2012, 109, 49-61. [CrossRef]

46. Docherty, K.M.; Balser, T.C.; Bohannan, B.J.M.; Gutknecht, J.L.M. Soil microbial responses to fire and interacting global change factors in a California annual grassland. Biogeochemistry 2012, 109, $63-83$. [CrossRef]

47. Úbeda, X.; Lorca, M.; Outeiro, L.R.; Bernia, S.; Castellnou, M. Effects of prescribed fire on soil quality in Mediterranean grassland (Prades Mountains, north-east Spain). Int. J. Wildland Fire 2005, 14, 379-384. [CrossRef]

48. Pereira, P.; Úbeda, X.; Mataix-Solera, J.; Oliva, M.; Novara, A. Short-term changes in soil Munsell colour value, organic matter content and soil water repellency after a spring grassland fire in Lithuania. Solid Earth 2014, 5, 209-225. [CrossRef]

49. Rundel, P.W. Fire as an ecological factor. In Physiological Plant Ecology I-Responses to the Physical Environment; Lange, O.L., Nobel, P.S., Osmond, C.B., Ziegler, H., Eds.; Springer: Berlin, Germany, 2012; pp. 501-538.

50. Song, Y.T.; Zhou, D.W.; Zhang, H.X.; Li, G.D.; Jin, Y.H.; Li, Q. Effects of vegetation height and density on soil temperature variations. Chin. Sci. Bull. 2013, 58, 907-912. [CrossRef]

51. Sharrow, S.H.; Wright, H.A. Effects of fire, ash, and litter on soil Nitrate, temperature, moisture and Tobosagrass production in the Rolling Plains. J. Range Manag. 1977, 4, 197-270. [CrossRef]

52. Terefe, T.; Mariscal-Sancho, I.; Peregrina, F.; Espejo, R. Influence of heating on various properties of six Mediterranean soils. A laboratory Study. Geoderma 2008, 143, 273-280. [CrossRef]

53. Lu, J.; Zheng, F.; Li, G.; Bian, F.; An, J. The effects of raindrop impact and runoff detachment on hillslope soil erosion and soil aggregate loss in the Mollisol region of Northeast China. Soil Tillage Res. 2016, 161, 79-85. [CrossRef]

54. Tongway, D.J.; Ludwig, J.A. The nature of landscape dysfunction in rangelands. In Landscape Ecology Function and Management; Ludwig, J.A., Tongway, D.J., Freudenberger, D., Noble, J., Hodgkinson, K., Eds.; CSIRO Publishing: Canbbera, Australia, 2003; pp. 49-61.

55. DeBano, L.F. The role of fire and soil heating on water repellency in wildland environments: A review. J. Hydrol. 2000, 231-232, 195-206. [CrossRef]

56. Johansen, M.P.; Hakonson, T.E.; Breshears, D.D. Post-fire runoff and erosion from rainfall simulation: Contrasting forests with shrublands and grasslands. Hydrol. Process. 2001, 15, 2953-2965. [CrossRef]

57. Nyman, P.; Smith, H.G.; Sherwin, C.B.; Langhans, C.; Lane, P.N.J.; Sheridan, G.J. Predicting sediment delivery from debris flows after wildfire. Geomorphology 2015, 250, 173-186. [CrossRef] 
58. Langhans, C.; Nyman, P.; Noske, P.J.; Van der Sant, R.E.; Lane, P.N.J.; Sheridan, G.J. Post-fire hillslope debris flows: Evidence of a distinct erosion process. Geomorphology 2017, 295, 55-75. [CrossRef]

59. Nyman, P.; Sheridan, G.J.; Smith, H.G.; Lane, P.N.J. Evidence of debris flow occurrence after wildfire in upland catchments of south-east Australia. Geomorphology 2011, 125, 383-401. [CrossRef]

60. Sheridan, G.J.; Nyman, P.; Langhans, C.; Cawson, J.; Noske, P.J.; Oono, A.; Van der Sant, R.; Lane, P.N.J. Is aridity a high-order control on the hydro-geomorphic response of burned landscapes? Int. J. Wildland Fire 2016, 25, 262-267. [CrossRef]

61. Sheridan, G.J.; Lane, P.N.J.; Noske, P.J. Quantification of hillslope runoff and erosion processes before and after wildfire in a wet Eucalyptus forest. J. Hydrol. 2007, 343, 12-28. [CrossRef]

62. Gabet, E.J. Sediment transport by dry ravel. J. Geophys. Res.-Solid Earth 2003, 108, 2049. [CrossRef]

63. Florsheim, J.L.; Chin, A.; O'Hirok, L.S.; Storesund, R. Short-term post-wildfire dry-ravel processes in a chaparral fluvial system. Geomorphology 2016, 252, 32-39. [CrossRef]

64. Stout, J.E. A field study of wind erosion following a grass fire on the Llano Estacado of North America. J. Arid Environ. 2012, 82, 165-174. [CrossRef]

65. Wagenbrenner, N.S.; Germino, M.J.; Lamb, B.K.; Robichaud, P.R.; Foltz, R.B. Wind erosion from a sagebrush steppe burned by wildfire: Measurements of PM10 and total horizontal sediment flux. Aeolian Res. 2013, 10, 25-36. [CrossRef]

66. Germino, M.J. Wind Erosion Following Wildfire in Great Basin Ecosystems; Graet Basin Factsheet Series-Information and Tools to Conserve and Restore Great Basin Ecosystems, 2015. Available online: https://www.sagegrouseinitiative.com/wp-content/uploads/2015/10/Wind-Erosion-FollowingWildfire-Grt-Basin-fs-6.pdf (accessed on 18 May 2019).

67. Danin, A. Dust trapping by Anabasis Articulata in the Extreme Desert. Israel Vegetation Online, 2012. Available online: http://flora.org.il/books/vegetation-of-israel-and-neighboring-countries/chapter-g/local_ veg_g5/ (accessed on 18 May 2019).

68. McFadden, L.D. Strongly dust-influenced soils and what they tell us about landscape dynamics in vegetated aridlands of the southwestern United States. In The Web of Geological Sciences: Advances, Impacts, and Interactions; Bickford, M.E., Ed.; Geological Society of America: Boulder, CO, USA, 2013; pp. 501-532.

69. Paige, G.B.; Stone, J.J.; Guertin, P. Evaluation of Post-Wildfire Runoff and Erosion on Semiarid Ecological Sites; USDA Forest Service Proceedings RMRS-P-36; USDA Forest Service: Washington, DC, UAS, 2005. Available online: https://www.fs.fed.us/rm/pubs/rmrs_p036/rmrs_p036_536_538.pdf (accessed on 18 May 2019).

70. Morris, R.H.; Bradstock, R.A.; Dragovich, D.; Henderson, M.K.; Penman, T.D.; Ostendorf, B. Environmental assessment of erosion following prescribed burning in the Mount Lofty Ranges, Australia. Int. J. Wildland Fire 2014, 23, 104-116. [CrossRef]

71. Smith, H.G.; Sheridan, G.J.; Lane, P.N.J.; Noske, P.J.; Heijnis, H. Changes to sediment sources following wildfire in a forested upland catchment, southeastern Australia. Hydrol. Process. 2011, 25, 2878-2889. [CrossRef]

72. Clark, P.E.; Nielson, R.M.; Lee, J.; Ko, K.; Johnson, D.E.; Ganskopp, D.C.; Chigbrow, J.; Pierson, F.B.; Hardegree, S.P. Prescribed fire effects on activity and movement of cattle in mesic Sagebrush steppe. Rangel. Ecol. Manag. 2017, 70, 437-447. [CrossRef]

73. Clark, P.E.; Lee, J.; Ko, K.; Nielson, R.M.; Johnson, D.E.; Ganskopp, D.C.; Pierson, F.B.; Hardegree, S.P. Prescribed fire effects on resource selection by cattle in mesic sagebrush steppe. Part 2: Mid-summer grazing. J. Arid Environ. 2016, 124, 398-412. [CrossRef]

74. Pearson, S.M.; Turner, M.G.; Wallace, L.L.; Romme, W.H. Winter habitat use by large ungulates following fire in northern Yellowstone National Park. Ecol. Appl. 1995, 5, 744-755. [CrossRef]

75. Hobbs, N.T.; Spowart, R.A. Effects of prescribed fire on nutrition of mountain sheep and mule deer during winter and spring. J. Wildl. Manag. 1984, 48, 551-560. [CrossRef]

76. Tracy, B.F.; McNaughton, S.J. Elk grazing and vegetation responses following a late season fire in Yellowstone National Park. Plant Ecol. 1997, 130, 111-119. [CrossRef]

77. Pickford, G.D. The influence of continued heavy grazing and of promiscuous burning on spring-fall ranges in Utah. Ecology 1932, 13, 159-171. [CrossRef]

78. West, N.E.; Yorks, T.P. Vegetation responses following wildfire on grazed and ungrazed sagebrush semi-desert. J. Range Manag. 2002, 55, 171-181. [CrossRef] 
79. Vermeire, L.T.; Crowder, J.L.; Wester, D.B. Semiarid rangeland Is resilient to summer fire and postfire grazing utilization. Rangel. Ecol. Manag. 2014, 67, 52-60. [CrossRef]

80. Gates, E.A.; Vermeire, L.T.; Marlow, C.B.; Waterman, R.C. Reconsidering rest following fire: Northern mixed-grass prairie is resilient to grazing following spring wildfire. Agric. Ecosyst. Environ. 2017, 237, 258-264. [CrossRef]

81. Miller, R.F.; Chambers, J.C.; Pyke, D.A.; Pierson, F.B.; Williams, C.J. A Review of Fire Effects on Vegetation and Soils in the Great Basin Region: Response and Ecological Site Characteristics; Gen. Tech. Rep. RMRS-GTR-308; Rocky Mountain Research Station, Forest Service, U.S. Department of Agriculture: Fort Collins, CO, USA, 2013; p. 126. Available online: http://sagestep.org/pdfs/rmrs_gtr308.pdf (accessed on 18 May 2019).

82. Stritar, M.L.; Schweitzer, J.A.; Hart, S.C.; Bailey, J.K. Introduced ungulate herbivore alters soil processes after fire. Biol. Invasions 2010, 12, 313-324. [CrossRef]

83. Stavi, I.; Barkai, D.; Knoll, Y.M.; Zaady, E. Livestock grazing impact on soil wettability and erosion risk in post-fire agricultural lands. Sci. Total Environ. 2016, 573, 1203-1208. [CrossRef]

84. Smith, H.G.; Sheridan, G.J.; Lane, P.N.J.; Nyman, P.; Haydon, S. Wildfire effects on water quality in forest catchments: A review with implications for water supply. J. Hydrol. 2011, 396, 170-192. [CrossRef]

85. Mast, M.A.; Murphy, S.F.; Clow, D.W.; Penn, C.A.; Sexstone, G.A. Water-quality response to a high-elevation wildfire in the Colorado Front Range. Hydrol. Process. 2016, 30, 1811-1823. [CrossRef]

86. Son, J.H.; Kim, S.; Carlson, K.H. Effects of wildfire on river water quality and riverbed sediment phosphorus. Water Air Soil Pollut 2015, 226, 26. [CrossRef]

87. Mansilha, C.; Duarte, C.G.; Melo, A.; Ribeiro, J.; Flores, D.; Marques, J.E. Impact of wildfire on water quality in Caramulo Mountain ridge (Central Portugal). Sustain. Water Resour. Manag. 2019, 5, 319-331. [CrossRef]

88. Mansilha, C.; Carvalho, A.; Guimarães, P.; Marques, J.E. Water quality concerns due to forest fires: Polycyclic Aromatic Hydrocarbons (PAH) contamination of groundwater from mountain areas. J. Toxicol. Environ. Health Part A 2014, 77, 806-815. [CrossRef]

89. FAO. Wildfre Prevention in the Mediterranean. A Key Issue to Reduce the Increasing Risks of Mediterranean Wildfres in the Context of Climate Changes-Position Paper. In Proceedings of the 5th International Wildland Fire Conference, Avignon, France, 5-8 April 2011. Available online: http://www.fao.org/forestry/4031906791969d1427714a896b8faeee2aa501.pdf (accessed on 18 May 2019).

90. Davies, K.W.; Boyd, C.S.; Bates, J.D.; Hulet, A. Winter grazing can reduce wildfire size, intensity and behaviour in a shrub-grassland. Int. J. Wildland Fire 2015, 25, 191-199. [CrossRef]

91. Scasta, J.D.; Weir, J.R.; Stambaugh, M.C. Droughts and wildfires in western U.S. rangelands. Rangelands 2016, 38, 197-203. [CrossRef]

92. Moritz, M.A.; Parisien, M.A.; Batllori, E.; Krawchuk, M.A.; Van Dorn, J.; Ganz, D.J.; Hayhoe, K. Climate change and disruptions to global fire activity. Ecosphere 2012, 3, 49. [CrossRef]

93. Mills, A.J.; O'Connor, T.G.; Donaldson, J.S.; Fey, M.V.; Skowno, A.L.; Sigwela, A.M.; Lechmere-Oertel, R.G.; Bosenberg, J.D. Ecosystem carbon storage under different land uses in three semi-arid shrublands and a mesic grassland in South Africa. S. Afr. J. Plant Soil 2005, 22, 183-190. [CrossRef]

94. Urbanski, S. Wildland fire emissions, carbon, and climate: Emission factors. Forest Ecol. Manag. 2014, 317, 51-60. [CrossRef]

95. Myhre, G.; Shindell, D.; Bréon, F.M.; Collins, W.; Fuglestvedt, J.; Huang, J.; Koch, D.; Lamarque, J.F.; Lee, D.; Mendoza, B.; et al. Anthropogenic and natural radiative forcing. In Climate Change 2013: The Physical Science Basis. Contribution of Working Group I to the Fifth Assessment Report of the Intergovernmental Panel on Climate Change; Stocker, T.F., Qin, D., Plattner, G.K., Tignor, M., Allen, S.K., Boschung, J., Nauels, A., Xia, Y., Bex, V., Midgley, P.M., Eds.; Cambridge University Press: Cambridge, UK, 2013.

96. Vončina, A.; Ferlan, M.; Eler, K.; Batič, F.; Vodnik, D. Effects of fire on carbon fluxes of a calcareous grassland. Int. J. Wildland Fire 2014, 23, 425-434. [CrossRef]

97. Singh, A.; Agrawal, M. Acid rain and its ecological consequences. J. Environ. Biol. 2008, 29, $15-24$.

98. Strand, T.; Gullett, B.; Urbanski, S.; O’Neill, S.; Potter, B.; Aurell, J.; Holder, A.; Larkin, N.; Moore, M.; Rorig, M. Grassland and forest understorey biomass emissions from prescribed fires in the southeastern United States-RxCADRE 2012. Int. J. Wildland Fire 2016, 25, 102-113. [CrossRef]

99. Luvuno, L.; Biggs, R.; Stevens, N.; Esler, K. Woody encroachment as a social-ecological regime shift. Sustainability 2018, 10, 2221. [CrossRef] 
100. Schlesinger, W.H.; Reynolds, J.F.; Cunningham, G.L.; Huenneke, L.F.; Jarrell, W.M.; Virginia, R.A.; Whitford, W.G. Biological feedbacks in global desertification. Science 1990, 247, 1043-1048. [CrossRef]

101. Mata-González, R.; Figueroa-Sandoval, B.; Clemente, F.; Manzano, M. Vegetation changes after livestock grazing excludion and shrub control in the southern Chihuahuan Desert. West. N. Am. Nat. 2007, 67, 63-70. [CrossRef]

102. Kosmas, C.; Detsis, V.; Karamesouti, M.; Kounalaki, K.; Vassiliou, P.; Salvati, L. Exploring long-term impact of grazing management on land degradation in the socio-ecological system of Asteroussia Mountains, Greece. Land 2015, 4, 541-559. [CrossRef]

103. Twidwell, D.; Fuhlendorf, S.D.; Taylor, C.A., Jr.; Rogers, W.E. Refining thresholds in coupled fire-vegetation models to improve management of encroaching woody plants in grasslands. J. Appl. Ecol. 2013, 50, 603-613. [CrossRef]

104. Wester, D.B.; Bryant, F.C.; Tjelmeland, A.D.; Grace, J.L.; Mitchell, S.L.; Edwards, J.T.; Hernández, F.; Lyons, R.K.; Clayton, M.K.; Rideout-Hanzak, S.; et al. Tanglehead in southern Texas: A native grass with an invasive behavior. Rangelands 2018, 37-44. [CrossRef]

(C) 2019 by the author. Licensee MDPI, Basel, Switzerland. This article is an open access article distributed under the terms and conditions of the Creative Commons Attribution (CC BY) license (http://creativecommons.org/licenses/by/4.0/). 